\title{
AFRICA REVIEW
}

\section{AN UP-TO-DATE GEOGRAPHICAL, HISTORICAL, PO- LITICAL AND ECONOMIC SUMMARY OF THE AFRICAN COUNTRIES}

Prepared by : F. Pauwels, P. Van Damme, D. Theeten, C. De Keyser, S. Hoste.

\section{BOTSWANA}

1. Official name: Republic of Botswana.

2. Geography:

2.1. Situation: Botswana is situated in southern Africa between $18^{\circ} \mathrm{S}$ and $27^{\circ} \mathrm{S}, 25^{\circ} \mathrm{E}$ and $29^{\circ} \mathrm{E}$. It is landlocked between Namibia in the north and west, South Africa in the south and Zimbabwe in the north-east.

\subsection{Total area: $582000 \mathrm{~km}$.}

2.3. Natural regions: the landscape is gently sloping, varying in height between 900 and $1200 \mathrm{~m}$. It is covered with grasses and bushes (park savanna). In the SW lies a dry sandy savanna, called the Kalahari semi-desert. The three main drainage areas are the Limpopo in the east, the Okavango delta in the north and the Molopo in the south.

2.4. Climate: the tropic of Capricorn divides the country into two parts: climate ranges from tropical in the north to temperate in the south. The conditions are generally hot and dry with summer rainfall. Night frost occurs in the south.

\section{Population:}


3.1. Total population: $1.2 \mathrm{mln}$ (1988), urban population: $20 \%$.

3.2. Population density: 2.1 per $\mathrm{km}^{2}$. (mid 1988).

3.3. Population growth rate: $3.5 \%$ (1980-1985).

3.4. Capital: GABORONE, 110.973 (mid 1988).

3.5. Languages: English (official, commercial), Setswana.

3.6. Religion: traditional religions, Christian (30\%).

4. History:

Migrations of the Bantu tribes succeeded each other until the Zulu invasions in the early 19 th century. The territory became partly a British protectorate, a British colony and a German colony. In 1920 the Native Advisory Council was established after reunification of the three territorial entities. In 1961 the Constitution gave a restricted legislative power to the Advisory Council and in 1965 proposals for internal self government led to independence in September 1966.

5. Nature of political system:

The legislature is the 38-member National Assembly, 32 of which are elected for five years by universal adult suffrage. The Assembly elects a President who has executive power. He appoints a Cabinet responsible to the assembly. The President is an ex-officio member of the Assembly. The approval of a House of Chiefs is needed for some measures but they cannot veto legislation. The house of Chiefs comprises the chiefs of the eight principal tribes of Botswana.

Voting qualifications: universal adult suffrage over 21.

6. Economy:

GDP: agriculture: $6 \%$, industry: $49 \%$, services: $46 \%$ (1985).

Employment: agriculture: 70\%, industry: 13\%, services:17\% (1980). 


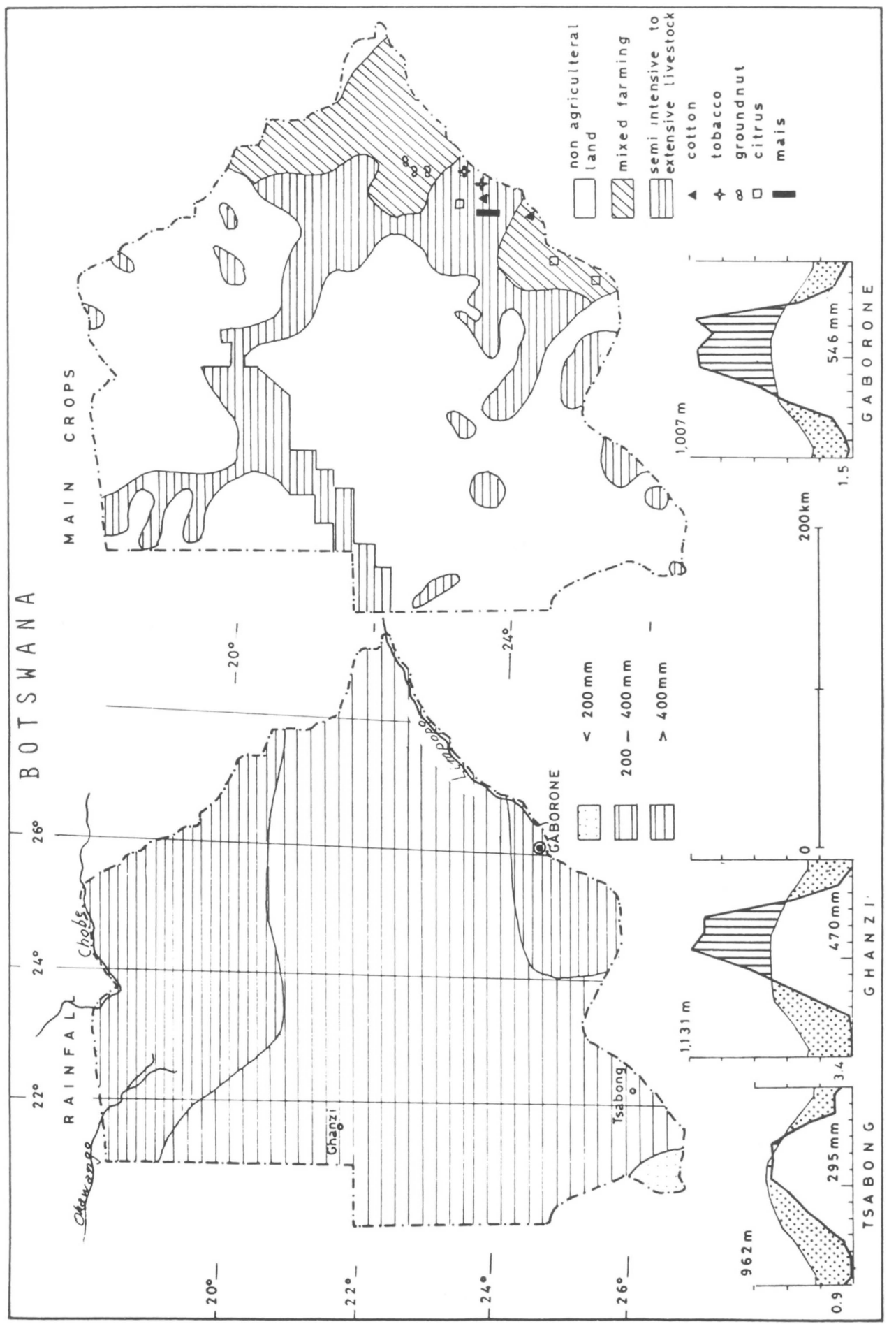




\subsection{Mining:}

The diamond industry with an annual production of 12.0 mln carats (1984) makes Botswana the third world producer. Copper and nickel (together $40000 \mathrm{t}$ in 1981), and manganese are also exploited. Important deposits of coal await exploitation. Salt mines and gypsum deposits can lead to the development of a chemical industry.

\subsection{Agriculture:}

$2 \%$ of the total area is arable land or cultivated with permanent crops (1984). Traditional tribes with subsistence agriculture produce mostly sorghum and maize with very low yields. Small vegetable production for local markets. Large quantities of food have to be imported every year.

\subsection{Livestock:}

$73 \%$ of the total area is permanent pasture (1984). Livestock is very important and is the keystone of the economy. There are approximately $2.7 \mathrm{mln}$ heads of cattle (1984), 600000 goats, 130-150000 sheep, 120000 donkeys and an uncertain number of pigs and chickens ( $1 \mathrm{mln}$ ). The livestock development program aims at increasing productivity through breeding methods, animal health service centers, the digging of wells and game ranching.

\subsection{Forestry and woodland:}

$1.6 \%$ of the total area (1984). Forest reserves are planned and tree cutting has been regulated by granting licences. Useful species are Baikiaea plurifuga (Zimbabwean teak), Pterocarpus angolensis and Burkea africana (Mukarati).

\subsection{Fishery:}

A variety of edible fish are found in rivers of the Okavango Delta.

\subsection{Industry:}

Is poorly developed. Textile and food industries are growing. The Botswana Meat Corporation is by far the largest industrial plant. Tourism industry is gradually developing. 
6.7. Weights, measures and currency:

1 Pula $(\mathrm{P})=100$ Thebe

1 US $\$=2.05 \mathrm{P}($ March 1989)

7. Trade:

Exports amount to $87 \mathrm{mln}$ US \$ (1976), subdivided as follows: mineral products (45\%), meat and canned meat (40\%). The main client is South Africa.

Imports amount to $140 \mathrm{mln}$ US \$ (1975). The main suppliers are South Africa and the United Kingdom.

8. Miscellaneous:

Literacy: 25\% in English, 35\% in Setswana (1980 estimates).

World Bank classification: Botswana belongs to the lower middle-income economies with a GDP per capita of 840 US \$ (1985).

Membership of international organisations:

GATT, ILO, IMF, OAU, UN, WHO, African Development Bank, Arab Bank for Economic Development in Africa (recipient), Commonwealth,Economic Commission for Africa, Southern African Development Co-ordination Conference, World Bank.

Botswana is a signatory to the Lome Convention (EEC-ACP).

Embassy of Botswana in Belgium: Tervurenlaan 169

1150 Brussel

Tel. 02/735.20.70

Belgian Embassy in Botswana: Martin Mwamba Road 3815

Olymbio Park

P.O. Box 31204

Lusaka, Zambia 


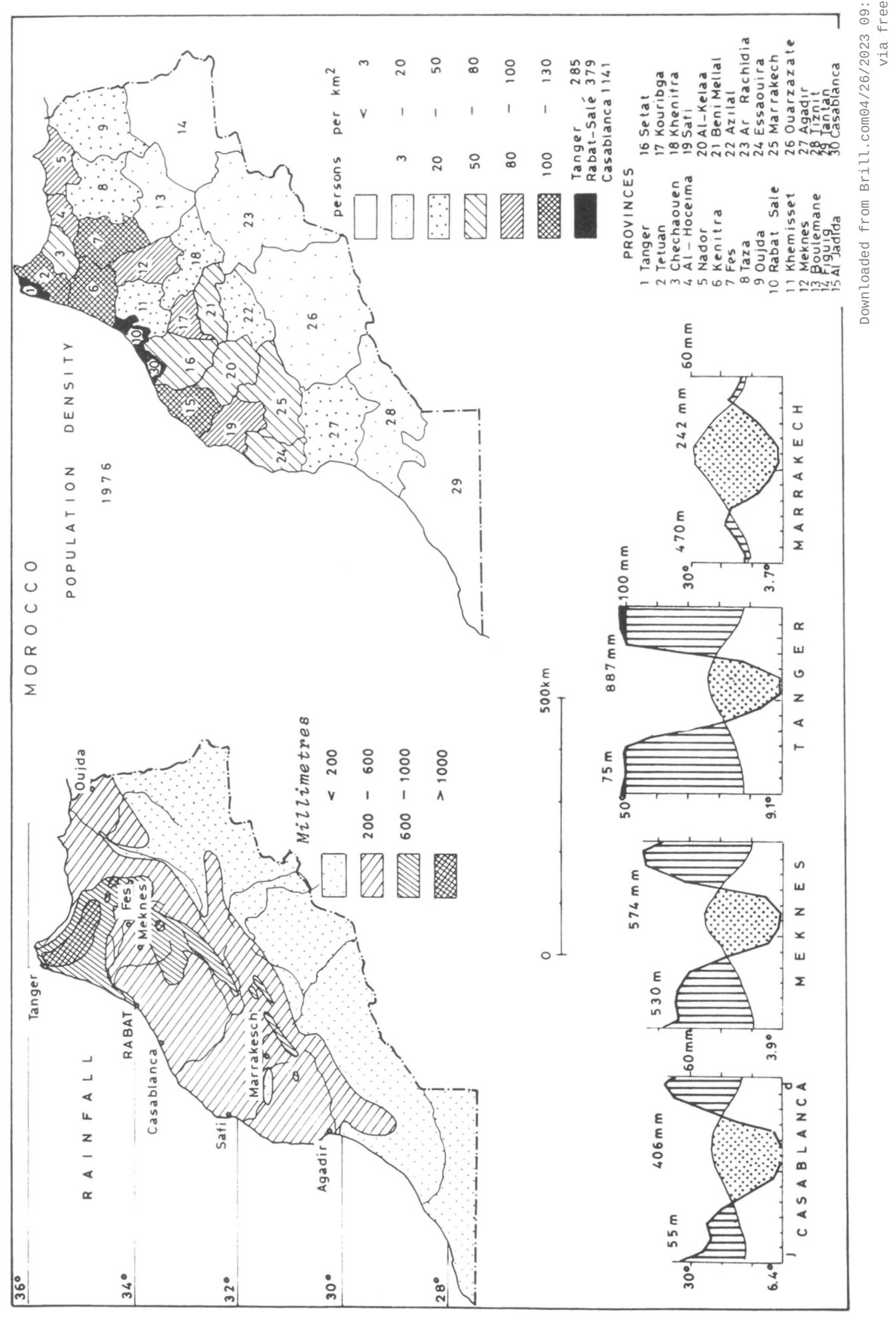

